\title{
Forms of Firms’ Nonlinear Internationalization
}

\author{
Tiia Vissak
}

\author{
University of Tartu, Estonia \\ Corresponding author.Email: tiia.vissak@ut.ee
}

\begin{abstract}
This paper aims to contribute to the internationalization literature by explaining which forms of nonlinear internationalization firms can experience. It explains that nonlinear internationalization can occur in terms of markets, customers, products, sales channels and foreign operation modes. The paper concludes that internationalization should not be only studied in terms of a firm's activities by each market but also by its activities by each sales channel, product, customer, and foreign operation mode in each market. Even if total sales continue increasing in a specific market, this does not mean that the firm has not experienced nonlinear internationalization.
\end{abstract}

Keywords: internationalization, de-and re-internationalization, nonlinear internationalization, serial nonlinear internationalization.

\section{INTRODUCTION}

Internationalization processes have received considerable research attention since the 1970 s but still, some research gaps exist. For instance, internationalization literature has mainly focused on firms' establishment and initial growth. (Serial) nonlinear internationalization has not received enough research attention yet in the literature although according to Sousa et al. [28, p. 12], "non-linear pattern of internationalization is common" and Vissak and Masso [37] found that most firms are nonlinear internationalizers. Thus, several gaps still need filling in the literature on nonlinear internationalization. For example, Sousa et al. [28, p. 1] stated that "Despite the growing relevance of this phenomenon for firms and managers, we are yet to gain a clear understanding of how and why firms choose to re-enter previously exited foreign markets" while Nguyen and Kock [20, p. 96] noted: "knowledge of how small firms choose their products, markets, and entry strategies in reinternationalization has remained unclear".

Studies on (serial) nonlinear internationalization have mainly focused on nonlinearities by markets [28]; [20]. In addition to the need of studying firms' nonlinear internationalization in terms of entered and exited markets, there is a need to focus on their nonlinearities in terms of sales channels, operation modes, products and customers. Some authors have already provided some evidence of other nonlinearities: for instance, Swoboda et al. [30] noted that firms can change their choice of foreign operation modes, Gabrielsson et al. [15] concluded that firms can both increase and reduce the number of sales channels during their internationalization process, Nguyen and Kock [20] found that some firms reenter markets with new products, while according to Vissak et al. [38], sometimes getting orders from new customers results in re-entering some foreign markets. However, such nonlinearities still need more research attention.

This paper aims to contribute to the internationalization literature by showing that a firm can experience nonlinear internationalization in terms of entered markets, sales channels, foreign operation modes, customers and products. It starts from a review of the existing nonlinear internationalization literature. After presenting some hypothetical examples, we will provide some managerial and research implications.

\section{LITERATURE REVIEW}

In terms of studying nonlinear internationalization, most authors have focused on either full or partial exits: either withdrawing completely from all foreign markets or only exiting from one/more foreign markets but retaining at least some international activities in others (see, for example, [2]; [5]; [8]; [9]; [10]; [17]; [19]; [24]; [25]; [30]; [31]; [32]). Several authors have also studied re-internationalization: restoring previous foreign market activities - for instance, re-entering the exited markets fully or partially ([11]; [14]; [18]; [28]; [29]; [40]). For 
example, according to Vissak [34, p. 566], reinternationalization means "reentry to $/ . . . /$ specific markets from where the firm has previously exited /.../ as well as entering different foreign markets instead of those that were exited".

Some authors have also focused on serial nonlinear internationalization: exiting and re-entering markets several times ([21]; [35]; [37]). For instance, Bernini et al. [4, p. 1060] stated that intermittent exporters "repeatedly enter, withdraw from, and re-enter exporting activity as a whole", Sousa et al. [28] concluded that serial nonlinear internationalization is common for occasional exporters and firms that have irregular internationalization patterns and Chen et al. [6, p. 154] found that "market exit and re-entry among exporting firms is a regular occurrence".

Some authors have paid attention to operation mode changes during a firm's internationalization. For instance, Asmussen et al. [1], Benito et al. [3], Francioni et al. [13], Gabrielsson and Pelkonen [16], Javalgi et al. [18], Olejnik and Swoboda [22], Pedersen et al. [26] and Sousa et al. [28] stated that firms can both increase and decrease the scale of operations. For example, Chetty [7] concluded: "with internationalisation, the method of operation not only changes to reflect more commitment of resources but also becomes more diverse". Benito and Welch [2], on the other hand, noted that firms can experience "switching to operation modes that entail a lower level of commitment". Moreover, according to Vissak [34, p. 566], re-internationalization means "restoration of resource commitment to specific markets from where the firm has previously exited, or where it had reduced its involvement, as well as /.../ using entry modes with a higher resource commitment than after deinternationalization".

In addition to changing foreign operation modes, firms' use of sales channels can also change. For example, Romanello and Chiarvesio [27] found that as internationalization evolves, some firms' choice of sales channels changes: they may decide to reduce or stop using some - especially, if they were not efficient enough or if their need for such channels diminished (for instance, if they already found enough contacts at trade fairs) - but also start using some others: for instance, create partnerships with companies that have wide distribution networks. A firms' decision to change its use of sales channels may depend on financial considerations and also on the distance and importance of its target markets: if the market is far from its home market and if its share in the firm's total sales has remained low, then, for instance, visiting the market is too expensive and keeping a showroom there is not beneficial; on the other hand, the firm may still consider filling unsolicited orders received via its website [21].

Some firms may also continue on some markets after losing their previous customers if they manage to find new ones; however, some firms have to exit some markets and later try re-entering them. Sometimes, depending on customers' projects causes such fluctuations: for instance, if they do not need certain products - like machinery [35] or doors [21] - every year, then firms have to find several customers from each country if they expect to achieve stable sales. Thus, project businesses often experience nonlinear internationalization as projects are temporary [23]; [39]. On the other hand, such businesses may still manage to sell some spare parts to their customers even if they do not order the main products every year [21]; [35]. In addition, firms that rely on unsolicited export orders or mainly find customers from trade fairs also experience frequent export fluctuations if such orders are unstable [12].

Entering foreign markets also means making decisions regarding which products to offer in which market and when to start offering other products and drop current ones [28]; [33]. For instance, a machinery producer may offer some standardized machinery but also customize some of its machines to meet customers' needs; consequently, its sales by products may fluctuate considerably depending on what their customers (who do not necessarily order annually) need in a specific year [35]. Sometimes introducing new products or modifying current products can be also beneficial for re-entering markets, while sometimes it helps to find additional customers in a firm's current markets [14]; [21].

From the above we can conclude that during the internationalization process, firms can de- and reinternationalize once or several times. Some firms experience this phenomenon in terms of entered markets, while some also in terms of operation modes, sales channels and/or customers.

\section{DISCUSSION OF FOUR FICTITIOUS CASES}

The following section discusses four fictitious cases of European firms (see Tables 1-8). These tables were created to demonstrate which kinds of nonlinearities firms can experience in their internationalization. It was intended to create fictitious cases of serial nonlinear internationalizers that would differ in terms of export shares, foreign market selection and internationalization pace. For creating them, all the literature cited in the previous section [1]-[40] was used. Only integers (numbers without decimal places) were used in these tables to make them easier to follow.

Case A (see Tables 1-5) shows that even if a firm's export share remains relatively stable, a firm can experience several fluctuations in terms of markets (see Table 1): it can exit and re-enter several markets; moreover, its exports by markets can increase or decrease and total exports can be also volatile, but its export share 
alone does not show that. For instance, if the firm's turnover and exports both decrease by two times, its export share remains the same, but this does not mean that this firm has not experienced any nonlinearities in its internationalization.

Table 1. Firm A's total sales (in million EUR)

\begin{tabular}{|l|c|c|c|c|c|c|c|c|}
\hline & 2013 & 2014 & 2015 & 2016 & 2017 & 2018 & 2019 & 2020 \\
\hline Home & 1 & 3 & 6 & 4 & 9 & 6 & 8 & 4 \\
\hline Europe 1 & 0 & 1 & 0 & 0 & 2 & 0 & 4 & 2 \\
\hline Europe 2 & 0 & 2 & 1 & 2 & 1 & 0 & 3 & 2 \\
\hline Europe 3 & 0 & 0 & 3 & 0 & 0 & 1 & 2 & 1 \\
\hline Asia 1 & 0 & 0 & 2 & 3 & 4 & 2 & 3 & 1 \\
\hline Africa 1 & 0 & 0 & 0 & 1 & 2 & 3 & 0 & 0 \\
\hline Exports & 0 & 3 & 6 & 6 & 9 & 6 & 12 & 6 \\
\hline Ex share, \% & 0 & 50 & 50 & 60 & 50 & 50 & 60 & 60 \\
\hline Total & 1 & 6 & 12 & 10 & 18 & 12 & 20 & 10 \\
\hline
\end{tabular}

Case A also shows that a firm's sales by sales channels can be even more volatile than its total sales by each country (see Tables 2-5). For instance, a firm might not generate sales from trade fairs every year but it may still continue exporting via agents or it may receive foreign orders via its online shop. Thus, even if its sales by markets do not decrease, the firm may still be a nonlinear internationalize in terms of sales by sales channels.

Table 2. Firm A's sales through local retailers (in million EUR)

\begin{tabular}{|l|c|c|c|c|c|c|c|c|}
\hline & 2013 & 2014 & 2015 & 2016 & 2017 & 2018 & 2019 & 2020 \\
\hline Home & 1 & 3 & 5 & 2 & 7 & 5 & 6 & 1 \\
\hline
\end{tabular}

Table 3. Firm A's sales at foreign trade fairs (in million EUR)

\begin{tabular}{|l|c|c|c|c|c|c|c|c|}
\hline & 2013 & 2014 & 2015 & 2016 & 2017 & 2018 & 2019 & 2020 \\
\hline Europe 1 & 0 & 1 & 0 & 0 & 1 & 0 & 1 & 0 \\
\hline Europe 2 & 0 & 2 & 0 & 0 & 0 & 0 & 1 & 0 \\
\hline Europe 3 & 0 & 0 & 3 & 0 & 0 & 0 & 0 & 0 \\
\hline Asia 1 & 0 & 0 & 2 & 2 & 3 & 1 & 2 & 0 \\
\hline Africa 1 & 0 & 0 & 0 & 1 & 2 & 2 & 0 & 0 \\
\hline Total & 0 & 3 & 5 & 3 & 6 & 3 & 4 & 0 \\
\hline
\end{tabular}

Case B shows that a firm's exports by country can continue increasing even if its sales by customers are very volatile - for instance, if the share of each customer in the firm's exports to a particular country fluctuates considerably - and even if it does not sell to all customers every year (see Table 6). Thus, to detect more nonlinearities, it is also important to collect data by the firm's customers in each country (but, unfortunately, only a few firms would agree to provide such data).
Table 4. Firm A's sales through foreign retailers (in million EUR)

\begin{tabular}{|l|c|c|c|c|c|c|c|c|}
\hline & 2013 & 2014 & 2015 & 2016 & 2017 & 2018 & 2019 & 2020 \\
\hline Europe 1 & 0 & 0 & 0 & 0 & 0 & 0 & 2 & 1 \\
\hline Europe 2 & 0 & 0 & 1 & 0 & 0 & 0 & 2 & 1 \\
\hline Europe 3 & 0 & 0 & 0 & 0 & 0 & 0 & 1 & 0 \\
\hline Asia 1 & 0 & 0 & 0 & 0 & 0 & 0 & 0 & 0 \\
\hline Africa 1 & 0 & 0 & 0 & 0 & 0 & 0 & 0 & 0 \\
\hline Total & 0 & 0 & 1 & 0 & 0 & 0 & 5 & 2 \\
\hline
\end{tabular}

Table 5. Firm A's online sales (in million EUR)

\begin{tabular}{|l|c|c|c|c|c|c|c|c|}
\hline & 2013 & 2014 & 2015 & 2016 & 2017 & 2018 & 2019 & 2020 \\
\hline Home & 0 & 0 & 1 & 2 & 2 & 1 & 1 & 3 \\
\hline Europe 1 & 0 & 0 & 0 & 0 & 1 & 0 & 1 & 1 \\
\hline Europe 2 & 0 & 0 & 0 & 2 & 1 & 0 & 1 & 1 \\
\hline Europe 3 & 0 & 0 & 0 & 0 & 0 & 1 & 1 & 1 \\
\hline Asia 1 & 0 & 0 & 0 & 1 & 1 & 1 & 1 & 1 \\
\hline Africa 1 & 0 & 0 & 0 & 0 & 0 & 1 & 0 & 0 \\
\hline Total & 0 & 0 & 1 & 5 & 5 & 4 & 5 & 7 \\
\hline
\end{tabular}

Case C shows that a firm's export share and exports by country can be relative stable but, at the same time, it can experience considerable nonlinearities in terms of selling particular products to each market: its exports of some products can decrease and increase, and even stop for some years (see Table 7). Thus, collecting data by products by each country would also help to detect additional nonlinearities (but, unfortunately, again, firms are relatively reluctant to share such data).

Case D shows that a firm can use various foreign operation modes in a particular country in different years: for instance, it can start from indirect exports via an agent; thereafter, establish a sales subsidiary and after that, a production subsidiary and/or also a joint venture (see Table 8). It can also stop exporting to a particular country but continue other operations - for instance, production or new product development - there. Thus, only looking at export numbers by markets may provide an incomplete understanding of a firm's foreign operations and thus, some other nonlinearities can be overlooked.

\section{CONCLUSIONS AND IMPLICATIONS}

Based on the literature review and four fictitious cases, we conclude that nonlinear internationalization should not be only studied in terms of a firm's activities by each market but also by its activities by each sales channel, foreign operation mode, product and customer in each market. Even if the firm's total sales or sales in a specific market continue increasing, this does not mean that it has not experienced nonlinear internationalization in a specific market in terms of a specific sales channel, operation mode, product and/or customer. 
Table 6. Firm B's sales by customers (in million EUR)

\begin{tabular}{|l|c|c|c|c|c|c|c|c|}
\hline & 2013 & 2014 & 2015 & 2016 & 2017 & 2018 & 2019 & 2020 \\
\hline Home country, customer A & 1 & 3 & 4 & 7 & 6 & 2 & 6 & 4 \\
\hline Europe 1, customer B & 1 & 2 & 2 & 4 & 3 & 2 & 0 & 0 \\
\hline Europe 1, customer C & 0 & 1 & 3 & 2 & 0 & 0 & 1 & 1 \\
\hline Total for Europe 1 & 1 & 3 & 5 & 6 & 3 & 2 & 1 & 1 \\
\hline Europe 2, customer D & 0 & 0 & 1 & 0 & 0 & 5 & 6 & 6 \\
\hline Europe 2, customer E & 0 & 0 & 0 & 1 & 2 & 1 & 3 & 4 \\
\hline Europe 2, customer F & 0 & 0 & 0 & 0 & 13 & 10 & 8 & 5 \\
\hline Total for Europe 2 & 0 & 0 & 1 & 1 & 15 & 16 & 17 & 15 \\
\hline Exports & 1 & 3 & 6 & 7 & 18 & 18 & 18 & 16 \\
\hline Export share, \% & 50 & 50 & 60 & 50 & 75 & 90 & 75 & 80 \\
\hline Total & 2 & 6 & 10 & 14 & 24 & 20 & 24 & 20 \\
\hline
\end{tabular}

Table 7. Firm C's sales by products (in million EUR)

\begin{tabular}{|l|c|c|c|c|c|c|c|c|}
\hline & 2013 & 2014 & 2015 & 2016 & 2017 & 2018 & 2019 & 2020 \\
\hline Home country, product A & 2 & 5 & 5 & 4 & 7 & 9 & 8 & 10 \\
\hline Home country, product B & 1 & 3 & 4 & 8 & 7 & 11 & 16 & 14 \\
\hline Total for home country & 3 & 8 & 9 & 12 & 14 & 20 & 24 & 24 \\
\hline Europe 1, product A & 0 & 1 & 1 & 0 & 0 & 0 & 1 & 3 \\
\hline Europe 1, product B & 0 & 1 & 0 & 2 & 3 & 1 & 2 & 4 \\
\hline Total for Europe 1 & 0 & 2 & 1 & 2 & 3 & 1 & 3 & 7 \\
\hline Europe 2, product A & 0 & 0 & 2 & 1 & 2 & 1 & 0 & 3 \\
\hline Europe 2, product B & 0 & 0 & 0 & 1 & 0 & 1 & 2 & 6 \\
\hline Europe 2, product C & 0 & 0 & 0 & 0 & 1 & 2 & 1 & 0 \\
\hline Total for Europe 2 & 0 & 0 & 2 & 2 & 3 & 4 & 3 & 9 \\
\hline Exports & 0 & 2 & 3 & 4 & 6 & 5 & 6 & 16 \\
\hline Export share, \% & 0 & 20 & 25 & 25 & 30 & 25 & 20 & 40 \\
\hline Total & 3 & 10 & 12 & 16 & 20 & 25 & 30 & 40 \\
\hline
\end{tabular}

Table 8. An overview of Firm D's foreign operation modes (x: yes, 0: no)

\begin{tabular}{|l|c|c|c|c|c|c|c|c|}
\hline & 2013 & 2014 & 2015 & 2016 & 2017 & 2018 & 2019 & 2020 \\
\hline Home country (local activities) & $\mathrm{X}$ & $\mathrm{X}$ & $\mathrm{X}$ & $\mathrm{X}$ & $\mathrm{X}$ & $\mathrm{X}$ & $\mathrm{X}$ & $\mathrm{X}$ \\
\hline Europe 1, exports via an agent & 0 & 0 & $\mathrm{X}$ & $\mathrm{X}$ & 0 & 0 & 0 & 0 \\
\hline Europe 1, a sales subsidiary & 0 & 0 & 0 & $\mathrm{X}$ & $\mathrm{X}$ & 0 & 0 & 0 \\
\hline Europe 1, a production subsidiary & 0 & 0 & 0 & 0 & 0 & $\mathrm{X}$ & $\mathrm{X}$ & $\mathrm{X}$ \\
\hline Europe 2, exports via an agent & 0 & 0 & 0 & $\mathrm{X}$ & $\mathrm{X}$ & 0 & 0 & 0 \\
\hline Europe 2, a sales subsidiary & 0 & 0 & 0 & 0 & $\mathrm{X}$ & $\mathrm{X}$ & 0 & 0 \\
\hline Europe 2, a production subsidiary & 0 & 0 & 0 & 0 & 0 & $\mathrm{X}$ & $\mathrm{X}$ & 0 \\
\hline Europe 2, a joint venture & 0 & 0 & 0 & 0 & 0 & 0 & 0 & $\mathrm{X}$ \\
\hline Home country (local activities) & $\mathrm{X}$ & $\mathrm{X}$ & $\mathrm{X}$ & $\mathrm{X}$ & $\mathrm{X}$ & $\mathrm{X}$ & $\mathrm{X}$ & $\mathrm{X}$ \\
\hline
\end{tabular}

For managers, the following can be suggested: 1) do not perceive foreign market exit as a failure: exiting foreign markets is almost inevitable, especially if your firm depends on projects and/or on orders at trade fairs; 2) an exit does not have to be final: sometimes a re-entry becomes possible and in such cases, such possibilities should be considered; 3 ) a re-entry does not have to restore all the activities that the firm had before a foreign market exit: sometimes, for instance, a different sales channel, product or operation mode may become more suitable; moreover, your firm's customer base can change; 4) a re-entry does not have to be final, either: sometimes, an exit may follow, and later, a re-entry again: this is also fully normal.

This paper was based on four fictitious cases. In the future, researchers could collect case study evidence but also survey data from different countries to get in-depth knowledge on the issue and, for example, also find out if home country, ownership form, size, industry or other characteristics affect firms' nonlinear internationalization in terms of markets, foreign operation modes, sales channels, products and/or 
customers. Such studies should encompass firms that exited all markets but also those that continued with some foreign activities. Finally, future researchers could compare serial nonlinear and other internationalizes to discover their similarities and differences - for instance, in terms of entered markets and used sales channels.

\section{REFERENCES}

[1] Asmussen, C.G., Benito, G.R.G., \& Petersen, B. 2009. Organizing foreign market activities: From entry mode choice to configuration decisions. International Business Review, 18(2): 145-155.

[2] Benito, G.R.G., \& Welch, L.S. 1997. Deinternationalization. Management International Review, 37(Special Issue 2): 7-25.

[3] Benito, G.R.G., Petersen, B., \& Welch, L.S. 2011. Mode combinations and international operations: theoretical issues and an empirical investigation. Management International Review, 51(6): 803-820.

[4] Bernini, M., Du, J., \& Love, J.H. 2016. Explaining intermittent exporting: Exit and conditional re-entry in export markets. Journal of International Business Studies, 47(9): 1058-1076.

[5] Calof, J.L., \& Beamish P.W. 1995. Adapting to foreign markets: Explaining internationalization. International Business Review, 4(2): 115-131.

[6] Chen, J., Sousa, C.M.P., \& He, X. 2019. Export market re-entry: Time-out period and price/quality dynamisms. Journal of World Business, 54(2): 154168.

[7] Chetty, S. 1999. Dimensions of internationalisation of manufacturing firms in the apparel industry. European Journal of Marketing, 3(1/2): 121-142.

[8] Crick, D. 2004. UK SMEs' decision to discontinue exporting: An exploratory investigation into practices within the clothing industry. Journal of Business Venturing, 19(4): 561-587.

[9] Crick, D., \& Chaudhry, S. 2006. International marketing strategy in the electronics industry: a follow-up investigation of UK SMEs 18 months after the export withdrawal decision. Journal of Strategic Marketing, 14(3): 277-292.

[10] Crick, J., Crick, M.D. \& Chaudhry, S. 2020. Entrepreneurial marketing decision-making in rapidly internationalising and de-internationalising start-up firms. Journal of Business Research, 113: 158-167.

[11] Dominguez, N. \& Mayrhofer, U. 2017. Internationalization stages of traditional SMEs: Increasing, decreasing and re-increasing commitment to foreign markets. International Business Review, 26(6): 1051-1063.

[12] Ellis, P. \& Pecotich, A. 2001. Social factors influencing export initiation in small and mediumsized enterprises. Journal of Marketing Research, 38(1): 119-130.

[13] Francioni, B., Musso, F., \& Vardiabasis, D. 2013. Key decisions and changes in internationalization strategies: The case of smaller firms. Journal of Strategic Marketing, 21(3): 240-259.

[14] Freeman, S., Deligonul, S., \& Cavusgil, T. 2013. Strategic re-structuring by born-globals using outward and inward-oriented activity. International Marketing Review, 30(2): 156-182.

[15] Gabrielsson, M., Kirpalani, V.H.M. \& Luostarinen, R. (2002). Multiple channel strategies in the European personal computer industry. Journal of International Marketing, 10(3): 73-95.

[16] Gabrielsson, M., \& Pelkonen, T. 2008. Born internationals: Market expansion and business operation mode strategies in the digital media field. Journal of International Entrepreneurship, 6(2): 4971.

[17] Gnizy, I., \& Shoham, A. 2014. Explicating the reverse internationalization processes of firms. Journal of Global Marketing, 27(4): 262-283.

[18] Javalgi, R.G., Deligonul, S., Dixit, A., \& Cavusgil, S.T. 2011. International market reentry: A review and research framework. International Business Review, 20(4): 377-393.

[19] Matthyssens, P., \& Pauwels, P. 2004. Strategic flexibility in export expansion: growing through withdrawal. International Marketing Review, 21(4/5): 496-510.

[20] Nguyen, H.L. \& Kock, S. 2016. Psychological traits, experiences, foreign language knowledge of entrepreneurs, and re-internationalization strategies of SMEs: a theoretical analysis. In: H. Etemad, S. Denicolai, B. Hagen, A. Zuchella (Eds.), The Changing Global Economy and its Impact on International Entrepreneurship, Edward Elgar Publishing, Cheltenham, pp. 96-116.

[21] Nummela, N., Vissak, T. \& Francioni, B. 2021. The interplay of entrepreneurial and non-entrepreneurial internationalization: an illustrative case of an Italian SME. International Entrepreneurship and Management Journal (in press), https://doi.org/10.1007/s11365-020-00673-y.

[22] Olejnik, E., \& Swoboda, B. 2012. SMEs' internationalisation patterns: descriptives, dynamics 
and determinants. International Marketing Review, 29(5): 466-495.

[23] Owusu, R.A., Sandhu, M. \& Kock, S. 2007. Project business: A distinct mode of internationalization. International Marketing Review, 24(6): 695-714.

[24] Ozkan, K.S.L. 2020. International market exit by firms: Misalignment of strategy with the foreign market risk environment. International Business Review, 29(6): 101741.

[25] Pauwels, P., \& Matthyssens, P. 1999. A strategy process perspective on export withdrawal. Journal of International Marketing, 7(3): 10-37.

[26] Pedersen, T.; Petersen, B., \& Benito, G.R.G. 2002. Change of foreign operation method: impetus and switching costs. International Business Review, 11(3): 325-345.

[27] Romanello, R. \& Chiarvesio, M. 2017. Turning point: when born globals enter post-entry stage. Journal of International Entrepreneurship, 15(2): 177-206.

[28] Sousa, C.M.P., He, X., Lengler, J. \& Tang, L. 2021. Foreign market re-entry: a review and future research directions. Journal of International Management, 27(2): 100848.

[29] Surdu, I., Mellahi, K. \& Glaister, K.W. 2019. Once bitten, not necessarily shy? Determinants of foreign market re-entry commitment strategies. Journal of International Business Studies, 50(3), 393-422.

[30] Swoboda, B., Olejnik, E., \& Morschett, D. 2011. Changes in foreign operation modes: Stimuli for increases versus reductions. International Business Review, 20(5): 578-590.

[31] Turcan, R.V., Mäkelä, M.M., Sørensen, O.J., \& Rönkkö, M. 2010. Mitigating theoretical and coverage biases in the design of theory-building research: An example from international entrepreneurship. International Entrepreneurship and Management Journal, 6(4): 399-417.

[32] Turner, C. 2012. Deinternationalisation: Towards a coevolutionary framework. European Business Review, 24(2): 92-105.

[33] Turner, C., \& Gardiner, P.D. 2007. Deinternationalisation and global strategy: the case of British Telecommunications (BT). Journal of Business \& Industrial Marketing, 22(7): 489-497.

[34] Vissak, T. 2010. Nonlinear internationalization: A neglected topic in international business research. In T. Devinney, T. Pedersen, \& L. Tihanyi (Eds.), Advances in international management. Vol. 23: The past, present and future of international business and management (pp. 559-580). New York: Emerald.

[35] Vissak, T., \& Francioni, B. 2013. Serial nonlinear internationalization in practice: A case study. International Business Review, 22(6): 951-962.

[36] Vissak, T. \& Francioni, B. 2020. Reinternationalization forms and impact factors: four cases. Problemy Zarządzania - Management Issues 28(1): 27-53.

[37] Vissak, T., \& Masso, J. 2015. Export patterns: Typology development and application to Estonian data. International Business Review, 24(4): 652664.

[38] Vissak, T., Francioni, B. \& Freeman, S. 2020. Foreign market entries, exits and re-entries: the role of knowledge, network relationships and decisionmaking logic. International Business Review 29(1): 101592.

[39] Welch, C. 2005. Multilateral organizations and international project business. International Business Review, 14(3): 289-305.

[40] Welch, C.L., \& Welch, L.S. 2009. Reinternationalisation: Exploration and conceptualization. International Business Review, 18(6): 567-577 